\title{
"NO MAN HATH DARED TO WRITE THIS THING AS YET": TRADITION AND THE INDIVIDUAL TALENT OF EZRA POUND
}

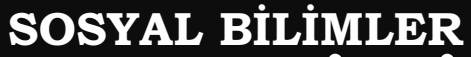 DERGISI}

ANKARA UNIVERSITY JOURNAL

OF SOCIAL SCIENCES

10.33537/sobild.2019.10.1.6

\section{Makale Bilgisi}

Gönderildiği tarih: 25-10-2018

Kabul edildiği tarih: 03-11-2018

Yayinlanma tarihi: 30.01.2019

\section{Article Info}

Date submitted: 25-10-2018

Date accepted: 03-11-2018

Date published: 30.01.2019

\section{Anahtar sözcükler}

Ingiliz-Amerikan Şiiri; Gelenek; T. S. Eliot; Ezra Pound

\section{Keywords}

Anglo-American Poetry; Tradition;

T.S. Eliot; Ezra Pound

\section{"HiÇ BiR KiMSE BU GÜNE KADAR CÜRET ETMEDi BUNU YAZMAYA": GELENEK VE EZRA POUND'UN BIREYSEL YETENEĞİ}

\section{S1la ŞENLEN GÜVENÇ}

Doç. Dr., Ankara Üniversitesi, Dil ve Tarih-Coğrafya Fakültesi, Ingiliz Dili ve Edebiyatı Anabilim Dalı.sguvenc@ankara.edu.tr

\section{Abstract}

There are many theories that define the role of the author, and the relationship between the author and the text, ranging from its status as a creator to that of a product of past traditions or discourses. Ezra Pound-one of the most innovative poets of the modernist period-has made significant contributions to poetry, and has had a vast influence on both English and American poetry. His chief aim was to improve the status of poetry and give it direction through his work. In this respect, although he gives a great deal of importance to the past and pays homage to past poets in line with T. S. Eliot's "Tradition and the Individual Talent", he also departs from it to create something 'new' and establish his own poetic authority. This study proposes that even though Pound aims to raise poetry to its rightful place, he does this at the expense of disregarding or excluding the public. The superior position that he occupies as poet and instructor, and his high and 'elitist' poetic standards cannot be easily met on the part of his readers and, in turn, create a certain 'intellectual gap' between the poet and the general public.

\section{$\ddot{O} z$}

Yazarın konumu ve rolünü belirlerken bir yaratıcıdan tutun da geçmiş geleneğin bir parçası ve ürünü olarak değerlendiren, yazar ile metin arasındaki ilişkiyi tanımlayan nice kuram mevcuttur. Şiire birçok yenilik getiren ve katkıda bulunan modernist şair Ezra Pound'un, hem Ingiliz hem de Amerikan șiirine büyük etkisi olmustur. T. S. Eliot "Tradition and the Individual Talent" ("Gelenek ve Bireysel Yetenek") başlikl çalışması ile geçmiş geleneğe ve şairlere büyük önem atfetmesine karşın, kaleme aldığı 'yeni' çalışmalarıyla kendi bireysel otoritesini de ortaya koymaktadır. Pound, şiiri hakettiği mevkiye getirmeyi hedeflese de, bunu, kendini üstün bir konuma getirerek ve okuyucuya erişiyemeyecekleri yüksek standartlar oluşturarak, halk ile kendisi arasında bir 'entelektüel fark' yaratmaktadır. Bu çalışmanın amact, Pound'un şiiri hak ettiği noktaya yükseltme arzusunun halkı göz ardı edip kısıtlı bir entelektüel kesime hitap etmesini ve dolayısıyla 'elitist' bir konum oluşturma çabasını ortaya koymaktir.

\section{Introduction: Tradition and the Individual Talent}

There have been a vast amount of criticism concerning the role and function of the poet, his or her place within the literary canon or tradition, and the poet's relationship with the produced text. The status of the poet ranges from being a creator using the language of the gods, to a position that minimizes him/her to a product of past traditions and discourses. In prehistoric periods, the function of the poet was similar to that of the priest or shaman who "directly encountered an audience, and was taken to speak for the will of the entire community" (Gitlin, 1981, p.77). Of course, this position has been questioned and challenged in the modern age. In "Tradition and the Individual Talent", T.S. Eliot suggests that works of the past constitute a tradition, which is, in turn, modified with the presence of the new produced work which alters it. Thus, "[n]o poet, no artist of any art, has his complete meaning alone. 
His significance, his appreciation is the appreciation of his relation to the dead poets and artists" (Eliot, 2012, p. 2555). For Eliot, the poet is rather a medium of expression within the so-called 'tradition'. The poet must know and acknowledge past poets starting with the Classics and, in turn, leave a mark on this tradition. This is related through an analogy of a catalyst, explaining that when oxygen and sulphur dioxide are mixed in the presence of platinum, they form sulphurous acid, which contains no trace of platinum. In other words, platinum is necessary for the chemical reaction to take place, but is not present in the thing produced. Thus, "the mind of the poet is the shed of platinum. It may partly or exclusively operate upon the experience of the man himself; but, the more perfect the artist, the more completely separate in him will be the man who suffers and the mind which creates; the more perfectly will the mind digest and transmote the passions which are its material" (Ibid., p. 2557). On the other hand, in "The Death of the Author", Roland Bathes emphasizes that since it is impossible for a text to be 'original', the author's relationship with the text's 'post-production' is considered to be over and completed. According to this theory, the text is not "a line of words releasing a single theological meaning (the message of the Author-God) but a multi-dimensional space in which a variety of writing, none of them original, blend and clash" and thus, the writer can never be original because (s)he imitates "a gesture that is always anterior" and his/her power rests in his/her ability to "mix writing" or "counter the ones with the others" (Barthes, 1966, p.170). For this reason, when expressing themselves, they should know that the inner thing they use to "translate" is "itself only a ready-formed dictionary, its words only explainable through other words, and so on indefinitely" and so life never does more than imitate the book, which is "only a tissue of signs, an imitation that is lost, infinitely deferred." (Ibid.)

\section{Tradition and Ezra Pound}

Ezra Pound -one of the most dedicated and innovative poets of the modernist period- has made significant contributions to poetry and has had a vast influence on British and American poetry ${ }^{1}$. Pound had a wide range of interests such as music, languages, different cultures, which he incorporated into his critical, economic, and poetic work. His chief aim was to improve the status of poetry and give it direction. In this respect, he attaches a great deal of importance to tradition, and especially to the Classics. In $A B C$ of Reading, Pound expresses that a "classic is

1 As for Pound's influence on Eliot, he introduced him to the works of English poets, proofread his work including The Waste Land and used his influence to get it published. 
classic not because it conforms to certain structural rules, or fits certain definitions (of which its author had quite probably never heard). It is classic because of a certain eternal and irrepressible freshness" (Pound, 1951a, p.13-14). He illustrates this point, the catalyst of the past and the present, in his poem "Histrion":

No man hath dared to write this thing as yet,

And yet I know, how that the souls of all men great

At times pass through us,

And we are melted into them, and are not

Save reflexions of their souls. (Pound, 2010, pp. 8-9, L 1-5)

Since tradition and the souls of past poets "pass through" the poet, (s)he is also the poets "Dante" and "[o]ne Francois Villon, ballad-lord and thief," (Ibid., L6-7). Moreover, many of Pound's works are re-workings of earlier -mainly Greek, AngloSaxon, Latin, Italian, Provencal, and Chinese- literatures. One such example is Pound's re-writing or interpretation of the Anglo-Saxon poem "Seafarer" about a sailor's lament regarding his lonely life full of hardships: "May I for my own self song's truth reckon,/Journey's jargon, how I in harsh days/Hardship endured oft." (Pound, 1928, p. 77, L 1-3) Pound, however, does not only re-write or imitate the Classics, but is informed about all kinds of literature -Eastern and Western- and incorporates them into his work in terms of style, subject matter, form etc. In Pound's poetry of "revolt", as defined by Cunliffe (1987, p.22), he merges the literary traditions and styles of Eastern and Western traditions to create a new 'catalyst'. Like the Classical poets, he employs a poetic diction quite elevated and distinct from ordinary language, but also adds references to several Classical writers, texts, idioms, historical persons and events, places, uses colloquial language, and other non-European forms such as Chinese verse, making it modern or even postmodern. The product is his 'individual talent'.

\section{The Individual Talent of Ezra Pound}

Modernism is as an umbrella term that encompasses several innovative artistic movements contributing to its development from different centres, such as London and Paris. As Taner Can has pointed out, "[e]ach of these movements represents a different a reaction against or an interpretation of modernisation's turbulent effects on the individual and society, and thus has a conceptual definition 
of its own" (Can, 26). Hence, a brief discussion of imagist poetry, one of the major movements classified under modernism, may help reveal Pound's elitist outlook on poetry and his place in this fervent time of experimentation in art and literature.

Ezra Pound played a central role in the imagist movement, which encouraged experimentation with different and abstract forms in verse rather than representational art. Pound claimed that poetry could be divided into phanopoeia (image), melopoeia (music), and logopoeia (meaning). Since the image presented an instant intellectual and emotional complex, making it like a vortex, his poems were built on images rather than symbols. In his manifestos on imagism, he advocated that poetry had to be cleared of all non-essential elements and only contain words that contributed to the poem, in order to present an intellectual and emotional complex. This point is probably best illustrated through the poems written in the form of the minimal haiku such as "In a Station of the Metro" (1911): "The apparition of these faces in the crowd;/ Petals on a wet black bough" and "L'Art, 1910": "Green arsenic smeared on an egg-white cloth,/Crushed strawberries! Come, let us feast/our eyes." (Pound, 1928, p.93), both of which focus on a single thought or image in seventeen syllables. As observed in thse poems, Pound was an advocator for free-verse. In one way, this break from the regularities expected in bourgeois culture was liberating, but on the other hand, departure from the pentameter and other mechanical rhythms of English-language verse was problematic because the pentameter-corresponding to the oral, or pre-literate culture- made poetry easier to memorize and more accessible.

Pound is one of the most important figures in restoring the employment of referential figures of speech as an imaginative instrument. Since it is assumed that the poet and his readers share a common cultural heritage, Pound demands that his readers are familiar with the Classics, Italian and English Renaissance, and Continental literature. Although it is not possible to know who was reading Eliot or Pound, it is "reasonable to surmise that their work was inaccessible to the bulk of the actual reading public" (Gitlin, 1981, p.73). In a lecture in which Eliot talks about public taste, he indicates that the poet writes for as large and diverse an audience as possible, but it actually the "half-educated and ill-educated" rather than the "uneducated" who constitute an obstacle, so the most useful poetry would be one that could go beyond the dominant public taste (Eliot in Gelpi: 156) 
Pound published a collection of his poems under the title Personae, and was one of the first to use the term in the modern sense. In order to write in an objective manner, Pound made use of personae or masks -similar to those worn by actors in Greek drama. His poem "Masks" emphasizes the idea of personae:

These tales of old disguisings, are they not

Strange myths of souls that found themselves among

Unwonted folk that spake an hostile tongue, $[\ldots]$

Old singers half-forgetful of their tunes,

Old painters color-blind come back once more,

Old poets skill-less in the wind-heart runes,

Old wizards lacking in their wonder-lore:

All they that with strange sadness in their eyes

Ponder in silence o'er earth's queynt devyse?

(Pound, 1982, p. 34, L1-14)

So, the role of the poet is to take up different disguises in order to narrate the tales of other "souls" from different points.

Pound's "Piere Vidal Old", written in the style of the songs by the medieval French Provençal troubadours includes a brief introduction:

It is of Piere Vidal, the fool par excellence of all Provence, of whom the tale tells how he ran mad, as a wolf, because his love for Loba of Penautier, and how men hunted him with dogs through the mountains of Cabaret and brought him for dead to the dwelling of this Loba (she-wolf) of Penautier, and how she and her Lord had him healed and made welcome, and he stayed some time at that court. He speaks: (Pound, 1928, p. 55)

The function of the direction provided as "He speaks:" is to distinguish the speaker in the poem from the actual poet. In this case, the speaker in the poem is Piere Vidal, a troubadour, and personae of this dramatic monologue. 
Another innovation is Pound's definition of 'epic' as a poem that included history, which he applied in his Cantos. Although his definition brings to mind narrative poems such as Homer's Odyssey or Dante's Divine Comedy, Pound's Cantos departs from them in his use of collage or the inclusion of excerpts from a variety of texts relating to American history, current events, and original quotations in many languages including French, Italian, and Chinese etc. Moreover, the parts of Cantos composed later on are organized in a spatial manner on the page, and emphasize fragmentation and discontinuity. Pound believed that poetry in a world without cultural unity or continuity would be fragmented. This fragmented poetic form can be observed as a response to a more general cultural situation: as an unconscious strategy for differentiating the poet from the "half-educated" audience, that "mob burdened by miserable taste and a pathetic need for continuities" (Gitlin, 1981, 75).

The Cantos, which is considered to be a modern epic recording the story of a struggle and employs complex references and association, modern history and personages, extracts or lines in various languages such as Latin, Italian, French, Chinese etc., which create a gap between the poet and the reader. This gap is felt even further when he refuses to enlighten them about certain matters, such the identity of Martin Van Buren -the Eighth President of the United States.

Pound aims to destroy the authority of the text by deconstructing the idea of a perfect faultless text such as in "E.P. Ode Pour L'election De Son Sepulchre":

For three years, out of key with his time,

He strove to resuscitate the dead art

Of poetry; to maintain "the sublime"

In the old sense. Wrong from the start--

[...]

The age demanded an image

Of its accelerated grimace,

Something for the modern stage

Not, at any rate, an Attic grace;

[...]

Daring as never before, wastage as never before.

Young blood and high blood, 
fair cheeks, and fine bodies;

fortitude as never before

frankness as never before,

disillusions as never told in the old days,

hysterias, trench confessions,

laughter out of dead bellies. (Pound, 2010, p.11)

This is done especially through misspelled or incomplete words as well as abstract thoughts, as in his poem "Ezra on the Strike" (1902):

I sez to Mandy, sure, sez I,

I'll bet thet air patch o' rye

Thet he'll squash 'em by-and-by,

And he did, by cricket! (Pound, 1982, p. 203, L 13-14)

\section{L'art pour 1'art}

In The Spectator, published at the beginning of the eighteenth century, Addison emphasizes the need to bring knowledge to people by claiming that the aim of the periodical was to educate and entertain the public:

It was said of Socrates that he brought down philosophy from heaven, to inhabit among men; and I shall be ambitious to have it said of me that I have brought philosophy out of closets and libraries, schools and colleges, to dwell in clubs and assemblies, at tea tables and in coffeehouses. (2000, p.2200)

This is, of course, an approach quite different from Ezra Pound's. Since poetry required a special kind of language usage, it would have made it difficult, or inaccessible to the general public. For Pound, understanding poetry demanded knowledge and effort on the part of the reader, and did not compromise his high standard in composition. He insisted that poetry was an art that demanded the most arduous application and study (Eliot, cited in Sutton, 1963, p. 35). Although he wrote didactic texts on various topics including how to $\operatorname{read}^{2}$, the general tendency in his poetic work has been to produce 'art for art's sake'. As Güzel Köşker

\footnotetext{
${ }^{2}$ See. Ezra Pound (1968). Literary Essays of Ezra Pound. Int. By T.S. Eliot. London: Faber and Faber Ltd.
} 
asserts, "American modernist poetry emerged in the early twentieth century and focused on novelty, renewal, and rebirth from the classical materials by reworking them in order to achieve meaning in the face of horrible wars and technological changes in the twentieth century" (Güzel Köşker, 2016, p. 6) The innovative aspect of modernism can be seen not only in the transcendence of the literary boundaries but also in the demand it makes on individuals to renew themselves. In this respect, Ayça Vurmay examines the "blurring" of the distinctions between literature and music in modernism through the literary/musical term "nocturne", which she believes to account for the condition of modernism connected with the modernist transience, ambivalence, sharp fluctuations of mood, and the "modernist imperative" for individuals to 'make it new', or transform themselves in novel or even "grotesque" ways (Vurmay, 2014, p.154-158).

In line with modernism in general, American poetry of high modernism which emerged as "a reaction to, and outgrowth of, the Romantic ideology in the nineteenth century" (Gelpi, 1981)-is also considered as a kind of protest against the "public's refusal to acknowledge the legislative" function of poetry (Gitlin, 1981, p.66). In a lecture delivered in Pietermaritzburg, F. T. Prince underlines the influence of Eliot and Pound who set out to bring the rhythms of ordinary, living people into poetry by exclaiming that while the Romantic revolution in poetry was made by Englishmen, the twentieth-century revolution was to be made these two men who had to leave their "native country [America] for England." (Prince, 1966, p.1) Thus, Pound and Eliot left for England because the "[r]obust American society in the Progressive era afforded no reliable social basis for an artistic elite; its aristocracy was too small and shallowly rooted, its bourgeois audience too philistine, to sustain an avant-garde." (Ibid., p.66) In fact, Pound's "Cantico del Sole" is a humorous criticism of the rejection of art in contemporary American culture: "The thought of what America would be like/ If the Classics had a wide circulation/ Troubles my sleep," (Pound, 2010, p.81, L 1-3). Here, Pound substitutes the word "classics" for "pornography" in order to create a satirical and humorous effect in order to mock a judge's ruling that obscenity is acceptable in the classics due to its limited audience.

Moreover, even though Pound writes for the public -through publications and his inclination to educate them and 'improve' their taste in poetry etc., - he also rejects them by creating a kind of authority and superiority over them. T. S. Eliot recalls complaining about an article Pound wrote for The Criterion on the monetary theory of Gesell: "I [Eliot] asked you to write an article which would explain this 
subject to people who had never heard of it: yet you write as if your readers knew about it already, but had failed to understand it." (Eliot, cited in Sutton, 1963, p. 33). In the same manner, when William Carlos Williams wrote to Pound in 1908, suggesting that his new published book of poetry might perhaps be too obscure for his public, he replied:

As for the 'eyes of too ruthless public': damn their eyes. No art ever yet grew by looking into the eyes of the public, ruthless or otherwise. You can obliterate yourself and mirror God, Nature, or Humanity but if you try to mirror yourself in the eyes of the public, woe be unto your art. At least that's the phase of truth that presents itself to me. (Pound, 1951b, p. 37)

Gitlin defines the poet's position within the community as one in which the poet stands isolated. Artists make art, but not in circumstances of their own making and, as a result, "the artist tends not to be embedded in the larger community beyond his or her immediate milieu and professional clientele" (1981, p. 64). So, his or her image of the audience therefore becomes especially abstract:

For most of Western history, at least since the Neolithic cave painters and especially since the Renaissance, artists have needed to stand apart from the community; but previously they stood apart in order to be able to speak to it more clearly. By contrast, at least one main line of modernism-Pound, Joyce, and Beckett- casts a cold eye at the project of communicating to the contemporary community at large. What emerges is the ideal of writing as prayer or alchemy, of the writer who communes with God, or with the elect, or with the hopes for representatives of posterity. (Ibid.)

As such, the artist's relationship with the audience becomes problematic in the modern era. Pound, in order to raise poetry to its rightful place, disregarded the general public taste. Furthermore, he created an 'intellectual gap' between his work and the readers, by setting them high standards -knowledge of the Classics, foreign languages, the identification of complicated and sophisticated inferences, a good command of their native tongue and knowledge of foreign languages etc.,- that are difficult to meet. But perhaps, it is necessary for the artist to stand apart from the public in order to produce something 'new'. 


\section{Conclusion}

Pound is a poet of great importance for both Anglo-American poetry, due to the contributions he has made to modernist poetry. It is apparent that a poet who constitutes a place within the past tradition or the literary canon, is like Prometheus in that (s)he defies the 'gods', past tradition in order to establish himself/herself a 'new' place within this tradition. In the case of Pound, he attaches great importance to tradition, and has an impressive working knowledge of both the Classics and other works belonging to the Eastern and Western tradition, but he also challenges their authority with his unique style of writing, breaking away from the predominant forms and ideas in western tradition. This is also what makes him 'new', unique, and one of the foremost representatives of the modern vision. On the other hand, his success in establishing his standards beyond his intellectual milieu is questionable. Although Pound aims to raise the status of poetry to its high rightful place, he does not care a great deal about disseminating these ideas among the general public. The elitist style or voice employed by Pound -who believed that poetry should be challenging rather than easily consumed- excludes the common reader who might not have a command over the Classical texts, foreign language, Latin etc. Thus, the modernist vision that Pound sets up is one that he shares not with the general public.

\section{SOURCES}

Addison, J. (2000). The Aims of the Spectator. In The Norton Anthology English Literature Vol II. (pp. 2197-2201). New York: W.W. Norton \& Company Norton.

Barthes, R. (1996). The Death of the Author. In The Barthes Reader. Toronto: Harpen Collins Ltd.

Bradley, S. \& Beatty, R. C. \& Long, E. H. (ed.) (1962). The American Tradition in Literature. New York: W.W. Norton \& Co.

Can, Taner. (De)forming the Modernist Canon: Joseph Conrad and English Literary Modernism. Stuttgart: Ibidem, 2014.

Cunliffe, M. (1987). The Penguin History of Literature American Literature Since 1900. Harmondsworth: Penguin Books. 
Eliot, T.S. (2012). Tradition and the Individual Talent. In The Norton Anthology English Literature: The Twentieth Century and After. Vol. F (pp. 2554-2566). New York: W.W. Norton \& Co.

Gelpi, A. (1990). A Coherent Splendor: The American Poetic Renaissance, 1910-1950. Cambridge: Cambridge U Press.

Gitlin, T. (1981). Inaccessibility as Protest: Pound, Eliot, and the Situation of American Poetry. In Theory and Society, 10 (1), 63-80.

Güzel Köşker, N. (2016) Revision of Helen's Myth and A New Female Discourse in Hilda Doolittle's Helen in Egypt.In, Dil Dergisi, 167 (1), 5-20.

Pound, E. (1951a). ABC of Reading. London: Faber and Faber Ltd.

Pound, E. (1951b). The Letters of Ezra Pound 1907-1941. Ed. D.D. Paige. London: Faber and Faber Ltd.

Pound, E. (1968). Literary Essays of Ezra Pound. Int. by T.S. Eliot. London: Faber and Faber Ltd.

Pound, E. (1928). Ezra Pound Selected Poems. Int. London: Faber \& Faber Ltd.

Pound, E. (1982). Masks. In Collected Early Poems of Ezra Pound. Ed. Michael John King (p. 34). New York: New Direction Pub. Co.

Pound, E. (1982). Ezra on the Strike. In Collected Early Poems of Ezra Pound. Ed. Michael John King (p. 203). New York: New Direction Pub. Co.

Pound, E. (2010). New Selected Poems and Translations. Ed. By Richard Sieburth. New York: New Directions.

Prince, F. T. (1966). Modern Poetry in England. In Theoria: A Journal of Social and Political Theory, 27 (October), 1-8.

Rabate, J. M. (1986). Language, Sexuality, and Ideaology in Ezra Pound's Cantos. Albany: State University of New York Press. 
Sutton, W. (ed.) (1963). Ezra Pound a Collection of Critical Essays. New Jersey: Prentice-Hall.

Vurmay, M. A. (2014). “Musical Aspects of Kazuo Ishiguro's Nocturnes: Five Stories of Music and Nightfall'. In Littera. Vol 34, 149-159. 